\title{
Fission-Track 法による男鹿半島の新第三系の 凝灰岩の年代決定
}

\author{
Fission-Track Ages of Tuffs of the Neogen Tertiary in \\ Oga Peninsula, Akita Prefecture, Japan

西村 進 (Susumu Nishimura)*
石 田 志 朗 (Shiro Ishida)**

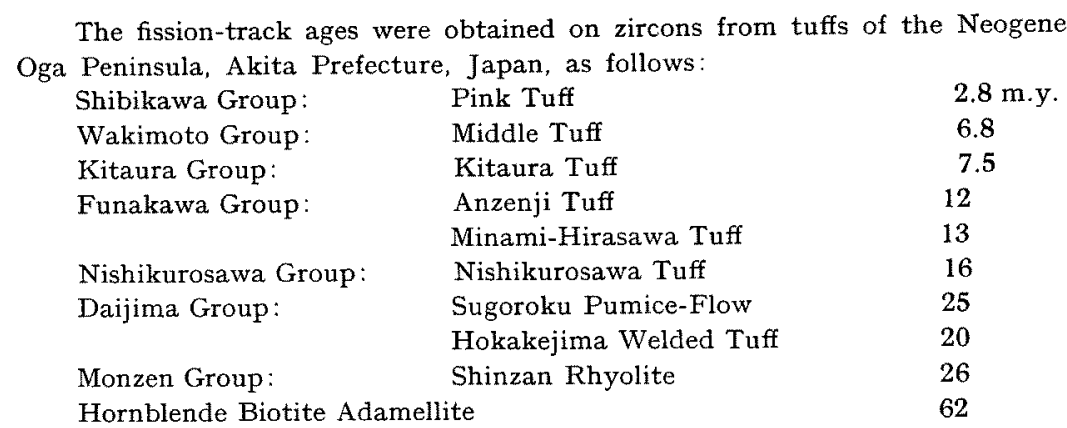

\section{1. 緒 言}

鉱物やガラスの年代が核分裂片の飛跡の計数によって 求められ出してから，種々の試料の年代の報告や，核分 裂法についての研究もなされて来大 (Fleischer et al., 1964; 阪上，1970; 西村，1970)。この方法に上万我国の 火山灰の年代決定も矢吹 - 島 (1970), Suzuki - Yamanami (1970)，西村・䈎鴆（1970）らによってなされてきた。

一方、詳細な生㬝序学による区分と正しく対応した地 質時代のスケールを作ることは地質学の重要な課題の一 つである。そこで，池辺展生を代表者とする総合研究班 も組まれ，その気運がのりつつある。また，男鹿半島は 秋田油田第三系の標式地として古くからよく調べ研究さ れていて(藤岡, 1959; Shinbo and Maiya, 1969)，その 凝灰岩の年代を決定することは重要かつ有意義と考えら れた。そこで，今回この方法を男鹿半島新第三系の凝兏 岩の年代決定に遥用した。

本研究に際して，大阪市立大学池辺展生教授を代表と
する総合研究 “日本の新第三紀の生㬝区分と絶対年代飞 よる国際対比”のメンバーの方々，ならでに池辺梖氏. 鈴木勝王氏をはじめ，石油資源開発株式会社の方々に大 变お世話になったので記して謝意を表する。

\section{2. 試料}

採集し，年代を求めることができた試料を次に列記す る。
鮹川圈
脇本層
試料番号 30（安田西）
北浦凮
33 , (安田西)
船川層
38 ，(羽立東）
船川層
2，(安全寺北)
西黒沢凮
27 , (南平沢)
台島層
6, (西黒沢)
台島層
24，(双六東）
23，(帆掛島北）
真山流紋岩 


\section{角閃石黒雲母アダメロ岩}

15，（赤島東）

\section{3. 方 法}

釷物やガラスの内部で核分裂がおこるとその分裂片と 物質の相互作用によって damage track を作る。適当な 試薬をえらび etching すれば顕微鏡下で観察し，計数す ることができる。この飛跡は鉱物やガラスがある一定の 温度以下になってから畜積して行く。

自発核分裂は半减期と存在量からみて，ほとんど ${ }^{238} \mathrm{U}$ のものとみられる。その鉣物の年代を求めるには ${ }^{238} \mathrm{U}$ 量を知る必要があるが、熱中性子の照射を括こなえば ${ }^{236} \mathrm{U}$ が誘導核分裂を抗こすのと天然物では ${ }^{295} \mathrm{U}$ と ${ }^{238} \mathrm{U}$ の原子数比が一定であることから同じく核分裂法によ。 て ${ }^{238} \mathrm{U}$ 量を求めることがでさる。

今，自発核分裂の䏅变定数老 $6.85 \times 10^{-17}\left(\mathrm{y}^{-1}\right)$ (Fleischer and Price, 1964) の值を用いて，その年代 Tが $10^{9}$ 年より若いとさは

$$
\mathrm{T}=6.12 \times 10^{-8} \phi \frac{\rho_{s}}{\rho_{i}}
$$

から，年代 $\mathrm{T}$ を求めることがでさる。ここで，中は全 中性子照射線量 $\left(\mathrm{cm}^{-2}\right) ， \rho_{i}$ と $\rho_{s}$ はそれぞれ etchされ た誘導核分裂片と自発核分裂片の飛跡の表面密度 $\left(\mathrm{cm}^{-2}\right)$ である。

試料からの必要鈗物の選別万法は，まず，試料水洗 (硬いりの小紛砕して後)，希塩酸 $80^{\circ} \mathrm{C}$ 程度で 20 分間 洗涤し，重液分離，磁選を行なって，最後に手選を行っ た。今回はその年代決定用の鉱物としてジルコンを用い t。

etching の条件は燃酸， $480^{\circ} \mathrm{C}, 1 \sim 1.5$ 分間で行った。

\section{4. 結果と考察}

現在までに処理した 25 試料のうち年代を求めること
ができたのは 10 試料で，その結果を Table 1 亿示す。 誤差籍囲を明記していないが，核分裂法による年代測 定には，次のよ5ないくつかの䜋差を生じさせる原因が 考皇られる。(i) 結晶内のウランの不均一分布 (ii) 飛跡 を数えるさいの誤差（iii）熱による飛跡の消減（iv）飛 跡がウラン以外の核種による誤差（v）照射中性子の線 量測定の誤差 (vi) 自発核分裂半減期の不磼かさなどで ある。

ジルコンを用いた今回の場合，(i）の誤差は出来る限 り排除した。（ii）の誤差の大部分は計数誤差で $3 \%$ 以下 にした。また個人誤差は $\rho_{i}, \rho_{s}$ ともに同㥞な判定の仕 万をしたので，今回の場合小さい田のと考えてよい。 (iii) は凝灰岩が主であるので急冷されていると考えら れるので問題にはならない。(iv) はジルコンに含まれる トリウムがウランに較べて少ししか含存しないので、こ の誤差る考えられない。（vi）は研究者によって㮔々の值 が用いられているが，現在までの結果 (西村，1972)を 考察し, $6.85 \times 10^{-17}\left(\mathrm{y}^{-1}\right)$ (Fleischer and Price, 1964) が適当上考古られる。しかし，今後更に，検討を加える 必要があ万弓。(v) の俱差は我々の方法（橋本他，1969） を用いれば、現在はぼ5\% 程度以下の䛊差で求めること ができるので，全体から考えて，誤差は20\%以下と考 えてよから。

\section{引用文献}

Fleischer, R.L. and Price, P.B. (1964), Decay constant for Spontaneous Fission of ${ }^{238} \mathrm{U}$, Phys, Rev., 133, B, 63-64.

蒜岡 一男 (1959)，户賀・船川，5万分の1地筫図巾 説明畫，地質獣查所

Kaneoka, I. and Suzuki, M. (1970), K-Ar and Fission-track Age of Some Obsidians from Japan, Jour. Geol. Soc. Jap., 76, 309 313.

Table 1. 男庶半島の新第三系の凝灰岩に含まれるジルコンの Fission-track 年代

\begin{tabular}{|c|c|c|c|c|c|}
\hline & $\begin{array}{l}\text { 試龭 } \\
\text { 番号 }\end{array}$ & $\rho s\left(\mathrm{~cm}^{-2}\right)$ & $\rho i \quad\left(\mathrm{~cm}^{-2}\right)$ & $\phi\left(c \mathrm{~m}^{-2}\right)$ & $\begin{array}{l}\text { Fission-track } \\
\text { age (m.y.) }\end{array}$ \\
\hline$ヒ^{\circ} ン ク$ 凝 灰 岩 & 30 & $2.1 \times 10^{6}$ & $4.5 \times 10^{7}$ & $1.0 \times 10^{15}$ & 2.8 \\
\hline 中部凝灰岩 & 33 & $3.5 \times 10^{6}$ & $3.2 \times 10^{7}$ & $1.0 \times 10^{15}$ & 6.8 \\
\hline 北浦 凝 灰 岩 & 38 & $2.8 \times 10^{6}$ & $2.5 \times 10^{7}$ & $1.1 \times 10^{15}$ & 7.5 \\
\hline 安全寺凝 灰 岩 & 2 & $5.6 \times 10^{6}$ & $2.8 \times 10^{7}$ & $1.1 \times 10^{15}$ & 12 \\
\hline 南平沢凝 灰岩 & 27 & $6.0 \times 10^{6}$ & $3.0 \times 10^{7}$ & $1.1 \times 10^{15}$ & 13 \\
\hline 西黑沢凝灰岩 & 6 & $4.3 \times 10^{6}$ & $1.8 \times 10^{7}$ & $1.1 \times 10^{15}$ & 16 \\
\hline 双宍輅不 流 & 24 & $7.1 \times 10^{6}$ & $1.9 \times 10^{7}$ & $1.1 \times 10^{15}$ & 25 \\
\hline 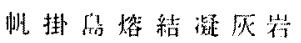 & 23 & $3.6 \times 10^{6}$ & $1.2 \times 10^{7}$ & $1.1 \times 10^{15}$ & 20 \\
\hline 点 111 流 紋 岩 & 12 & $3.1 \times 10^{6}$ & $8.0 \times 10^{6}$ & $1.1 \times 10^{15}$ & 26 \\
\hline 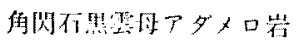 & 15 & $7.6 \times 10^{6}$ & $7.5 \times 10^{6}$ & $1.0 \times 10^{15}$ & 62 \\
\hline
\end{tabular}


橋本哲夫, 岩田志郎, 西村進, 中西孝, 阪上正信 (1969)，Fission-track 法に上る原子帄中性子東测 定，第9回日本アイソトーブ会翊報文集，231-234.

西村進 (1970)，核分裂片の飛跡の計数による年代 決定法，岩鈸，64，173-181。

西村進 (1972)， ${ }^{288} \mathrm{U}$ 自発核分裂の壊变定数の检 討，岩鉉，67，139-142.

西村進·篗鸣 貞雄 (1970)，Fission-track 法位よ る大阪層群とその相当㜿中の火山灰の年代測定，地 球科学， 24，222-224.

阪上 正信 (1970)，固体内の粒子トラック法とその発 展, 化学の領域, 24, 124-137.
Shinbo, K. and Maiya, S. (1969), Neogene Tertiary Planktonic Foraminiferal Zonation in the Japanese Oil Producting Provinces, Jap. Delegation 4th ECAFE Petrol. Symp., 1-15, Cambera.

Suzuki, M. and T. Yamanami (1970), Fission-track dating of the Uonuma Group, Jour. Geol. Soc. Jap., 76, 317-318.

矢吹 英婎・島誠 (1970)，フィショントラック による第四紀雇ジコンの年代測定，理研報告， 46. 59-62. 